\title{
O SÉCULO DA ENFERMAGEM
}

\author{
Darci Francisco dos Santos Junior (1) e Marina Nolli Bittencourt (2)
}

\section{EDITORIAL}

Já se passaram mais de 200 anos do advento da enfermagem moderna, e apesar de tanto tempo, volta e meia passamos por situações desafiadoras e inimagináveis. Mas, em tempos que profissões centenárias perecem e novas surgem, o que será de nós? Apesar de estarmos sendo reconhecidos em 2020, por meio da comemoração do ano internacional da Enfermagem pela Organização Mundial da Saúde, seremos futuramente esquecidos, ou reconhecidas pela história?

Antes de respondermos a essas questões, é importante revisitarmos os dados sobre o perfil da enfermagem no Brasil, que apontam que a nossa profissão é formada majoritariamente por mulheres, pretos e pardos. Populações que, historicamente, vivem a desigualdade, o preconceito e, porque não dizer, a miséria social em seu sentido mais amplo.

Sabendo disso, cabe à geração atual de enfermeiros se empoderar sobre a sua própria história, para que possamos modificar o futuro e reparar as mazelas e injustiças do passado. Que os nossos profissionais passem a reconhecer figuras históricas da enfermagem como Mary Jane Seacole, cujo passado foi esquecido por muito tempo, pois apesar de todos os seus esforços na guerra da Crimeia, foi recusada na equipe de Florence pelo simples fato de ser negra. Isso mostra que está na hora de escrevermos uma história mais justa, para que não sejamos acometidos pelos mesmos erros do passado.

Diante disso, será que ainda seguimos negligenciando, sem perceber, pessoas que seriam capazes de mudar o que hoje conhecemos como enfermagem? Será que nos calam, ou pior, nós nos deixamos calar sobre o que podemos ou não fazer em relação a nossa própria profissão? Será que foi necessária uma pandemia para que finalmente fossemos reconhecidos como essenciais por um serviço que realizamos, como ciência, há 200 anos? Tal mudança só poderá ocorrer quando lutarmos e nos empoderarmos enquanto uma ciência profissional essencial; e esperamos que não demore mais 200 anos para que isso ocorra.

Essa luta e empoderamento nos colocará a frente de desafios, que não serão mais difíceis do que vivemos em nosso passado de resistências a retrocesso, mas que poderão ser, de uma vez por todas, a nossa maior contribuição para o fortalecimento da profissão, e o desenvolvimento sustentável da população global. 
Também esperamos que, no futuro, você leitor não tenha que se deparar com nenhuma das problemáticas levantadas nesse texto, e que seja somente um texto sobre o quanto éramos ocupados demais com tantas responsabilidades da profissão, e que, por isso, tenha nos faltado um pouquinho de tempo para maior engajamento para chegarmos onde você chegou. Mas, caso você tenha se identificado, você é responsável por essa mudança, por isso, dê o pontapé inicial no seu trabalho, faça pesquisas e responda problemas, seja sempre referência onde quer que você vá, e não deixe se abalar por nada. A nossa Enfermagem depende do agora.

Esperamos que esse ano de reconhecimento da enfermagem vire um século de comemorações.

Instituição afiliada: 1- Universidade Federal do Amapá.

Dados da publicação: Artigo recebido em 10 de Outubro, revisado em 15 de Outurbro, aceito para publicação em 19 de Outubro e publicado em 29 de Outubro.

DOI: https://doi.org/10.36557/2674-8169.2020v2n11p09-11

Marina Nolli Bittencourt marinanolli@hotmail.com

c) (i)

This work is licensed under a Creative Commons Attribution 4.0 International

License. 